\title{
Direct uptake of organically derived carbon by grass roots and allocation in leaves and phytoliths: ${ }^{13} \mathrm{C}$ labeling evidence
}

\author{
Anne Alexandre ${ }^{1}$, Jérôme Balesdent ${ }^{1,4}$, Patrick Cazevieille ${ }^{3}$, Claire Chevassus-Rosset ${ }^{3}$, Patrick Signoret ${ }^{4}$, \\ Jean-Charles Mazur ${ }^{1}$, Araks Harutyunyan $^{2}$, Emmanuel Doelsch $^{3}$, Isabelle Basile-Doelsch ${ }^{1}$, Hélène Miche $^{1}$, and \\ Guaciara M. Santos ${ }^{2}$ \\ ${ }^{1}$ Aix-Marseille Université, CNRS, IRD, INRA, CEREGE UM34, 13545 Aix en Provence, France \\ ${ }^{2}$ Department of Earth System Science, University of California, B321 Croul Hall, Irvine, CA 92697-3100, USA \\ ${ }^{3}$ CIRAD, UPR Recyclage et risque, 34398 Montpellier, France \\ ${ }^{4}$ INRA UR 1119 GSE, 13100 Aix-en-Provence, France
}

Correspondence to: Anne Alexandre (alexandre@cerege.fr)

Received: 7 October 2015 - Published in Biogeosciences Discuss.: 10 December 2015

Revised: 12 February 2016 - Accepted: 20 February 2016 - Published: 18 March 2016

\begin{abstract}
In the rhizosphere, the uptake of low-molecularweight carbon $(\mathrm{C})$ and nitrogen $(\mathrm{N})$ by plant roots has been well documented. While organic $\mathrm{N}$ uptake relative to total uptake is important, organic $\mathrm{C}$ uptake is supposed to be low relative to the plant's $\mathrm{C}$ budget. Recently, radiocarbon analyses demonstrated that a fraction of $\mathrm{C}$ from the soil was occluded in amorphous silica micrometric particles that precipitate in plant cells (phytoliths). Here, we investigated whether and to what extent organically derived $\mathrm{C}$ absorbed by grass roots can feed the $\mathrm{C}$ occluded in phytoliths. For this purpose we added ${ }^{13} \mathrm{C}$ - and ${ }^{15} \mathrm{~N}$-labeled amino acids (AAs) to the silicon-rich hydroponic solution of the grass Festuca arundinacea. The experiment was designed to prevent $\mathrm{C}$ leakage from the labeled nutritive solution to the chamber atmosphere. After 14 days of growth, the ${ }^{13} \mathrm{C}$ and ${ }^{15} \mathrm{~N}$ enrichments $\left({ }^{13} \mathrm{C}\right.$ excess and ${ }^{15} \mathrm{~N}$ excess $)$ in the roots, stems and leaves as well as phytoliths were measured relative to a control experiment in which no labeled AAs were added. Additionally, the ${ }^{13} \mathrm{C}$ excess was measured at the molecular level, in AAs extracted from roots and stems and leaves. The net uptake of labeled AA-derived ${ }^{13} \mathrm{C}$ reached $4.5 \%$ of the total AA ${ }^{13} \mathrm{C}$ supply. The amount of AA-derived ${ }^{13} \mathrm{C}$ fixed in the plant was minor but not nil $(0.28$ and $0.10 \%$ of total $\mathrm{C}$ in roots and stems/leaves, respectively). Phenylalanine and methionine that were supplied in high amounts to the nutritive solution were more ${ }^{13} \mathrm{C}$-enriched than other $\mathrm{AAs}$ in the plant. This strongly suggested that part of AA-derived ${ }^{13} \mathrm{C}$ was absorbed and translocated into the plant in its orig-
\end{abstract}

inal AA form. In phytoliths, AA-derived ${ }^{13} \mathrm{C}$ was detected. Its concentration was on the same order of magnitude as in bulk stems and leaves $(0.15 \%$ of the phytolith $\mathrm{C})$. This finding strengthens the body of evidences showing that part of organic compounds occluded in phytoliths can be fed by $\mathrm{C}$ entering the plant through the roots. Although this experiment was done in nutrient solution and its relevance for soil $\mathrm{C}$ uptake assessment is therefore limited, we discuss plausible forms of AA-derived ${ }^{13} \mathrm{C}$ absorbed and translocated in the plant and eventually fixed in phytoliths, and implications of our results for our understanding of the $\mathrm{C}$ cycle at the soilplant-atmosphere interface

\section{Introduction}

In the rhizosphere, there are numerous known interactions between carbon $(\mathrm{C})$ and nitrogen $(\mathrm{N})$ processes that have yet to be accurately assessed in qualitative and quantitative terms for their consideration in carbon cycle models (Heimann and Reichstein, 2008). Among those interactions the uptake of low-molecular-weight $\mathrm{C}$ and $\mathrm{N}$ (e.g., organic acids, sugars and amino acids (AAs)) by plant roots (both mycorrhizal and non-mycorrhizal plants) has been well documented through labeling experiments using hydroponic solutions, artificial substrats or soils (e.g., Bardgett et al., 2003; Kuzyakov and Jones, 2006; Biernath et al., 2008; Jones et al., 2009a; Näsholm et al., 2009; Sauheitl et al., 2009; Ras- 
mussen et al., 2010; Gioseffi et al., 2012; Moran-Zuloaga et al., 2015). The aim of most of these studies was to investigate to what extent and under which conditions organic $\mathrm{N}$ could be utilized by plants as a direct source of $\mathrm{N}$ (i.e., without going through a mineralization step). The answers are still debated (Jones and Darrah, 1992; Jones et al., 2009a; Rasmussen et al., 2010; Moran-Zuloaga et al., 2015). In particular, evidence that plant roots can uptake labeled inorganic $\mathrm{C}$, which may bias the results from organic $\mathrm{N}$ uptake studies when using bulk measurement of dual-labeling $\left({ }^{13} \mathrm{C}\right.$ and ${ }^{15} \mathrm{~N}$ ), has been put forward (Biernath et al., 2008; Rasmussen et al., 2010). However, the use of molecular and positionspecific labeling technics can evidence the uptake and fixation of intact AAs (Sauheitl et al., 2009; Moran-Zuloaga et al., 2015). Organic $C$ uptake was also investigated through the estimation of the net uptake of glucose C. This uptake has been shown to be low relative to the plant's $C$ budget and has often been interpreted as the recapture of roots exudates (Jones and Darrah, 1992, 1993, 1996; Kuzyakov and Jones, 2006; Jones et al., 2009a). However, very recently, in the frame of a non-labeling experiment, radiocarbon analyses demonstrated that a fraction of $\mathrm{C}$ occluded in amorphous silica micrometric particles that precipitate in plant cells (phytoliths) came from old soil C (Santos et al., 2012; Reyerson et al., 2015). Silicon ( $\mathrm{Si}$ ) is the second-most-abundant element of the earth surface after oxygen. Its uptake by plants is widespread and generates, at the ecosystem scale, important fluxes from the soil to plants (Conley, 2002). For instance, Si absorption represents 2 to 10 times the amount of dissolved $\mathrm{Si}$ exported to stream water in tropical ecosystems (Alexandre et al., 2011). If part of the soil $\mathrm{C}$ uptake is linked to $\mathrm{Si}$ uptake in the rhizosphere, the involved flux may thus also be significant.

Here, we aim to investigate whether and to what extent $C$ derived from organic forms such as AAs can be absorbed by grass roots, fixed in the plant and ultimately feed the organic C occluded in phytoliths (phytC). We choose to focus on AAs as they are ubiquitous in soil organic matters of various residence times (Bol et al., 2009). For this purpose we added ${ }^{13} \mathrm{C}$ - and ${ }^{15} \mathrm{~N}$-labeled AAs to the Si-rich nutrient solution of the grass Festuca arundinacea. After 2 weeks of growth, the ${ }^{13} \mathrm{C}$ and ${ }^{15} \mathrm{~N}$ enrichments in the roots, stems/leaves and phytoliths of the grass (two replicates) were quantified. Enrichments were also measured at the molecular level (four replicates), in AAs of roots and stems/leaves. PhytC could not be analyzed at the molecular level, due to its very small concentration. The experiment was designed to prevent $\mathrm{C}$ leakage from the labeled nutritive solution to the chamber atmosphere.

\section{Material and methods}

\subsection{Hydroponic culture}

Festuca arundinacea, commonly referred to as tall fescue, is widely distributed globally as a forage and an invasive grass species (Gibson and Newman, 2001) and can adapt to a wide range of conditions. Festuca arundinacea was grown in hydroponic conditions for 24 days using an experimental procedure adapted from RHIZOtest (Bravin et al., 2010), a plant-based test recently standardized (ISO 16198:2015). Seventy-two plant-receiving pots (i.e., a cylinder closed at the bottom with a polyamide mesh of $30 \mu \mathrm{m}$ pore size, using an adjustable clamp) were inserted in three perforated platforms covering three $12 \mathrm{~L}$ tanks containing the nutrient solutions (24 plant pots per tank) (Fig. 1). This assembly enabled close contact between seeds or seedling roots and the nutrient solutions. In order to prevent escape of the Cand $\mathrm{N}$-bearing gas from the nutrient solution to the chamber atmosphere, O-rings sealed the plant pots to the perforated platform and the perforated platform to the tank. Each tank was hermetically connected to two $20 \mathrm{~L}$ containers (an input container filled with the nutrient solutions and a waste container). Additionally, after 10 days of germination, agar-agar (polysaccharide agarose) was added around the sprouts when they were $8 \mathrm{~cm}$ in height. At the same time, the germination solution was replaced by the growth solution labeled in ${ }^{13} \mathrm{C}$ and ${ }^{15} \mathrm{~N}$. The growth solution was entirely renewed once, after 8 days of growth. Otherwise the germination and nutritive

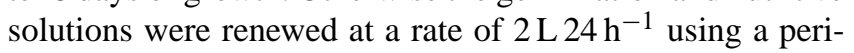
staltic pump (Fig. 1).

Overall, $10 \mathrm{~L}$ of germination solution and $64 \mathrm{~L}$ of growth solution were used per tank. Germination and the growth nutrient solution composition were described in detail in Guigues et al. (2014). The nutrient solutions included 42 of inorganic $\mathrm{N}\left(\mathrm{KNO}_{3}\right)$ and $18 \mathrm{mg} \mathrm{L}^{-1}$ of inorganic $\mathrm{C}$ in ethylenediaminetetraacetic acid (EDTA), added to chelate metals the plant uses for growth. The solutions were also supplemented with $105 \mathrm{mg} \mathrm{L}^{-1}$ of $\mathrm{SiO}_{2}$ (in the form of $\mathrm{SiO}_{2} \mathrm{~K}_{2} \mathrm{O}$ ). The growth chamber parameters were set at (day/night) $25 / 20^{\circ} \mathrm{C}, 75 / 70 \%$ relative humidity and $16 / 8 \mathrm{~h}$ with a photon flux density of $450 \mu \mathrm{mol}$ photons $\mathrm{m}^{-2} \mathrm{~s}^{-1}$ during the day.

At the end of the experiment, all samples were cleaned (to remove agar-agar), rinsed in deionized water and oven-dried at $50^{\circ} \mathrm{C}$ (to constant mass). When the tanks were filled (1st and 8th days of growth) and emptied (8th and 14th days of growth), the growth solution was sampled and kept frozen for future analyses.

\subsection{Isotope labeling}

In the two first tanks (two replicates), a mixture containing four ${ }^{13} \mathrm{C}$ - and ${ }^{15} \mathrm{~N}$-labeled AAs was added to the growth solution containing only inorganic $\mathrm{C}$ and $\mathrm{N}$ (as described 


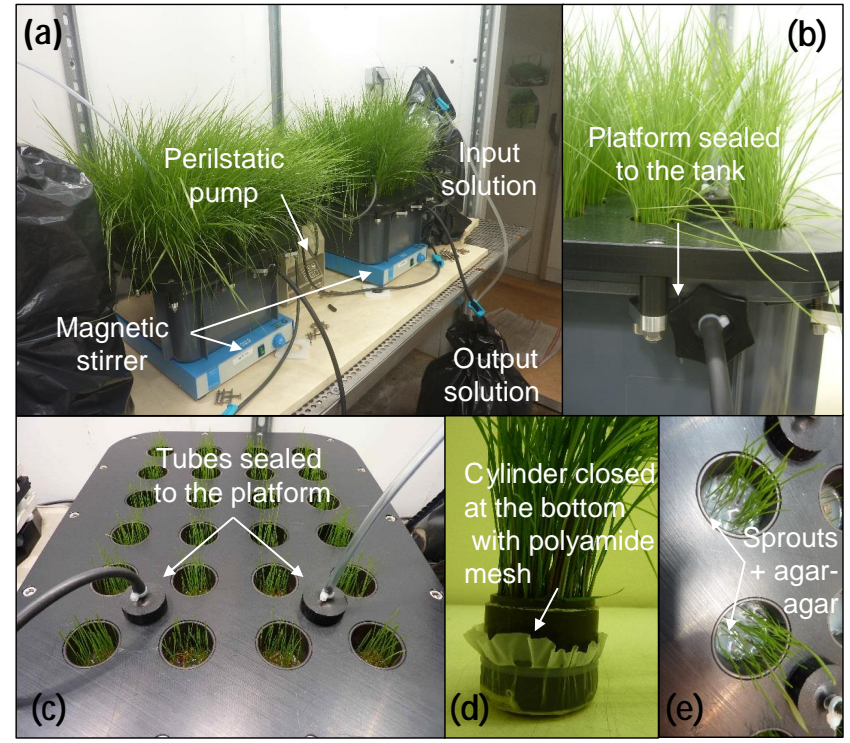

Figure 1. The labeling experiment in the growth chamber. (a) The two labeled tanks are connected to the solution containers. A peristaltic pump facilitates the solution renewals. (b) A platform is sealed to each tank. (c) Plant-receiving pots are cylinders closed at the bottom with a polyamide mesh. (d) Twenty-four plant-receiving pots are inserted into each platform. (e) In each pot, agar-agar was added around the sprouts to limit gas exchanges.

above). Those AAs were selected for their following characteristics: L-alanine (1-ALA) $(\mathrm{C} / \mathrm{N}=2.6)$ is ubiquist and occurs in high proportions in soils and plant proteins. The D-enantiomer of alanine (D-ALA), which is present in natural soils (Hill et al., 2011), was expected to be more resistant to degradation and, if absorbed, less subject to metabolization. Consequently, we speculated that D-ALA may accumulate as a waste product first in cell vacuoles and later in phytoliths. L-Phenylalanine (L-PHE) $(\mathrm{C} / \mathrm{N}=7.7)$ comprises a phenolic ring resistant to decomposition by microorganisms in soils, solutions or plants. L-Methionine (LMETH) $(\mathrm{C} / \mathrm{N}=4.3)$ is a sulfur amino acid expected to be recovered at low abundance in plants, but it is easily identifiable in gas chromatography-isotope ratio mass spectrometry (GC-IRMS). Commercial $97-99 \%{ }^{13} \mathrm{C}$ and ${ }^{15} \mathrm{~N}$ molecules (Euriso-top) were diluted with non-labeled amino acids to reach the following atom abundances: L-PHE $\left(19.51 \%{ }^{13} \mathrm{C}\right.$; $\left.19.13 \%{ }^{15} \mathrm{~N}\right)$; L-METH $\left(19.87 \%{ }^{13} \mathrm{C} ; 19.49 \%{ }^{15} \mathrm{~N}\right)$; L-ALA $\left(22.05 \%{ }^{13} \mathrm{C} ; 16.26 \%{ }^{15} \mathrm{~N}\right)$; and D-ALA $\left(7.43 \%{ }^{13} \mathrm{C} ; 0.37 \%\right.$ ${ }^{15} \mathrm{~N}$ ). All AAs were uniformly labeled except (i) D-ALA, which was not ${ }^{15} \mathrm{~N}$-labeled but was ${ }^{13} \mathrm{C}$-labeled on one atom (C-2), and (ii) an equivalent fraction of L-ALA because the labeled D-ALA was provided as a racemic mixture (DLALA). In each tank, the following amounts of AAs were added to the growth solution: PHE 249.9; MET 125.1; LALA 150.3; and D-ALA $125.2 \mathrm{mg}$. The total mixture (two tanks) represented $322 \mathrm{mg}$ of $\mathrm{C}(26.8 \mathrm{mmol})$ and $75.7 \mathrm{mg}$ of $\mathrm{N}(5.4 \mathrm{mmol})$, with average atom abundances of $18.15 \%$ ${ }^{13} \mathrm{C}$ and $13.43 \%{ }^{15} \mathrm{~N}$. The maximum AA concentration in the growth solution on the 1st or 8th day of the growth period was $0.225 \mathrm{mmol} \mathrm{L}^{-1}$, equivalent to 6.7 of ${ }^{13} \mathrm{C}$ and $1.6 \mathrm{mg} \mathrm{L}^{-1}$ of ${ }^{15} \mathrm{~N}$.

The third tank was only filled with the growth solution, without labeled AAs. It served as a control experiment to calculate the ${ }^{13} \mathrm{C}$ and ${ }^{15} \mathrm{~N}$ enrichments of the plants from the labeled tanks and to verify that ${ }^{13} \mathrm{C}$ and ${ }^{15} \mathrm{~N}$ derived from AAs (AA-derived ${ }^{13} \mathrm{C}$ and AA-derived ${ }^{15} \mathrm{~N}$ ), which may have contaminated the chamber $\mathrm{CO}_{2}$, were not photosynthesized by the plants.

\subsection{Analyses}

For each tank (one control tank and two labeled tanks) stems/leaves were separated from the roots into two samples. The six resulting samples were ground finer than $200 \mu \mathrm{m}$. After alkaline fusion, they were analyzed in $\mathrm{SiO}_{2}$ using inductively coupled plasma optical emission spectrometry (ICPOES).

For each sample, total $\mathrm{C},{ }^{13} \mathrm{C} /{ }^{12} \mathrm{C}$, total $\mathrm{N}$ and ${ }^{15} \mathrm{~N} /{ }^{14} \mathrm{~N}$ were determined after dry combustion by IRMS using a Carlo Erba NA 1500 elemental analyzer (EA) coupled to a Thermo-Finnigan Delta Plus mass spectrometer. Solutions were also analyzed for total $\mathrm{C}$ and ${ }^{13} \mathrm{C} /{ }^{12} \mathrm{C}$ by IRMS, after evaporation by dry combustion in tin capsules.

Proteic carbon was analyzed as the sum of 19 individual AAs representing ca. $95 \%$ of all AAs. Quantification and ${ }^{13} \mathrm{C} /{ }^{12} \mathrm{C}$ determination of individual AAs were performed using a GC-IRMS (Thermo Fisher Scientific). The extraction and purification procedure was a slightly modified version (Rubino et al., 2014) of the protocol developed by Amelung et al. (2006). Briefly, dry plant samples were hydrolyzed in $6 \mathrm{M} \mathrm{HCl}\left(20 \mathrm{~h}, 100^{\circ} \mathrm{C}\right)$. AAs were purified on Dowex $50 \mathrm{~W}$ X8 cation exchange resin (100-200 mesh size, Arcos Organics, Thermo Fisher Scientific), dried by rotary evaporation, re-dissolved in $0.1 \mathrm{M} \mathrm{HCl}$ and dried again by speedvacuum evaporation. AAs were separated and quantified as tert-butyldimethylsilyl derivatives (TBDMS-AA): AAs were dissolved in N-methyl-N-(t-butyldimethylsilyl) trifluoroacetamide (MTBSTFA) mixed with $1 \%$ trimethylchlorosilane (TMCS) (Sigma-Aldrich Co. Ltd.) and acetonitrile and heated at $120^{\circ} \mathrm{C}$ for $1 \mathrm{~h}$. One $\mu \mathrm{L}$ of TBDMS-AA solution was injected into the GC through a GCCIII combustion interface (Thermo Fisher Scientific). TBDMS-AAs were separated on a DB5 column $(30 \mathrm{~m}, 0.25 \mathrm{~mm}$ i.d., $0.25 \mu \mathrm{m}$ film thickness) with helium as a carrier gas. AA identification and quantification were performed using commercial mixtures of 20 proteinogenic AAs (Sigma Aldrich). Norvaline (SigmaAldrich Co. Ltd.) was added to plant samples before hydrolysis as an internal standard for quantification. Due to the addition of non-labeled carbon by TBDMS, AA ${ }^{13} \mathrm{C}$ enrichment was subsequently calibrated for each AA (Shinebarger et al., 200). Briefly, this calibration was based on the in- 
dependent measurement of ${ }^{13} \mathrm{C}$ of the TBDMS derivatives of the commercial AA and an additional set of four ${ }^{13} \mathrm{C}$ labeled AA (Rubino et al., 2014). The calibration equation involves the number of carbon atoms added as TBDM and the isotopic composition of the latter. This isotopic composition term disappears in the calculation of the isotope excess (cf. Eq. 1 below). When multiple peaks were encountered for a single AA, the main or the best individualized peak was chosen for both quantification and isotope ratio determination. The isotope ratios were calculated using ammonium sulfate IAEA-N1 $\left(\delta^{15} \mathrm{~N}=0.43 \pm 0.07 \%\right.$ ) , IAEA$\mathrm{N} 2\left(\delta^{15} \mathrm{~N}=20.41 \pm 0.07 \% \circ\right)$ and polyethylene IAEA CH7 $\left(\delta^{13} \mathrm{C}=-32.15 \pm 0.05 \% \circ\right)$ as secondary standards. The sucrose standard IAEA CH6 used as a control yielded a mean value of $10.43 \%$.

Phytoliths were extracted from plants using a highpurity protocol based on acid digestion and alkali immersion steps previously described in detail by Corbineau et al. (2013). Phytolith samples were observed in natural light microscopy to determine their morphological assemblage and check for the absence of residual organic matter particles. An additional purity check was done via scanning electron microscopy (SEM) (Corbineau et al., 2013; Reyerson et al., 2015). Then, phytolith samples were analyzed for their $\mathrm{C}$ and $\mathrm{N}$ contents, as well as their ${ }^{13} \mathrm{C}$ and ${ }^{15} \mathrm{~N}$ abundances by EA (Fisons NA $1500 \mathrm{NC}$ ) coupled to a continuous-flow IRMS (Finnigan Delta Plus). About 6-10 mg of phytolith concentrates were weighed using a pre-calibrated microbalance (Sartorius AG, Göttingen, Germany) into tin capsules $(5 \times 9 \mathrm{~mm}$ capsules, Costech Analytical Technologies Inc., Valencia, CA, USA) and prebaked at $100^{\circ} \mathrm{C}$ for $2 \mathrm{~h}$ to remove extraneous contaminants. To assure accurate integration and linearization of the raw analytical data obtained from the lower $\mathrm{C}$ and $\mathrm{N}$ peaks, we decreased the helium carrier flow rate and measured several aliquots of in-house collagen L-cystine $99 \%$ $\left(\delta^{13} \mathrm{C}=-28.74 \pm 0.13\right.$ and $\delta^{15} \mathrm{~N}=-6.14 \pm 0.07 \%$; from Sigma Aldrich Co. Ltd $)$ and atropine $\left(\delta^{13} \mathrm{C}=-21.30 \pm 0.06\right.$ and $\delta^{15} \mathrm{~N}=-2.90 \pm 0.10 \%$; from Costech 031042) as well as the internationally certified reference materials (e.g., USGS24 graphite $\delta^{13} \mathrm{C}=-16.05 \pm 0.07 \%$ and ammonium sulfate - IAEA-N $1 \delta^{15} \mathrm{~N}=+0.43 \pm 0.07 \%$ ). Aliquots of baked-clean silicon dioxide $\left(\mathrm{SiO}_{2}\right.$; mesh no. -325 , Sigma Aldrich, St. Louis, MO, USA) and fossil phytoliths (MSG70; Crespin et al., 2008) were also analyzed to provide independent blank data (Santos et al., 2010) and to check accuracy. To serve as quality assurance, note that the reproducibility obtained on the phytolith laboratory standard MSG70 was $\mathrm{SD} \pm 0.2 \% \circ$ for $\delta^{13} \mathrm{C}$ and $\delta^{15} \mathrm{~N}$, and $\mathrm{SD} \pm 0.01 \%$ for $\mathrm{C}$ and $\mathrm{N}$.

\subsection{Calculations}

For the control tank (no labeling), results are reported as $\delta$ values in per mil (\%o) relative to the Vienna Pee Dee Belem- nite (V-PDB) for $\delta^{13} \mathrm{C}$ and in permil (\%o) relative of the atmospheric $\mathrm{N}_{2}$ for $\delta^{15} \mathrm{~N}$. For the labeled tanks. AA-derived ${ }^{13} \mathrm{C}$ and AA-derived ${ }^{15} \mathrm{~N}$ plant concentration, recovery and net uptake were calculated on the basis of ${ }^{13} \mathrm{C}$ excess and ${ }^{15} \mathrm{~N}$ excess of a sample relative to the control tank samples according to Eq. (1):

$$
\begin{aligned}
{ }^{13} \mathrm{C} \text { excess } & \text { sample } \\
& (\%)={ }^{13} \mathrm{C} \text { atom } \\
& -{ }^{13} \mathrm{C} \text { atomple } \\
\text { control } & (\%),
\end{aligned}
$$

where ${ }^{13} \mathrm{C}$ atom ${ }_{\text {sample }}$ is the ${ }^{13} \mathrm{C}$ atom abundance of a sample (stems/leaves, roots or phytoliths) from a labeled tank and ${ }^{13} \mathrm{C}$ atom ${ }_{\text {control }}$ is the ${ }^{13} \mathrm{C}$ atom abundance of the same sample from the control tank.

The concentration of AA-derived ${ }^{13} \mathrm{C}$ in a sample, expressed in percent (\%) of total $\mathrm{C}$ in the sample, was calculated using Eq. (2):

$$
\begin{aligned}
& \text { AA-derived }{ }^{13} \mathrm{C}_{\text {sample }}(\%)={ }^{13} \mathrm{C} \text { excess } \\
& \left({ }^{13} \mathrm{C}\right. \text { atomple } \\
& \text { solution }
\end{aligned}
$$

Recovery of AA-derived ${ }^{13} \mathrm{C}$ in a sample, expressed in micrograms per gram $\left(\mu \mathrm{g} \mathrm{g}^{-1}\right)$ of the dry matter weight $(\mathrm{dwt})$, was calculated using Eq. (3):

$$
\begin{aligned}
& \text { Recovery AA-derived }{ }^{13} \mathrm{C}\left(\mu \mathrm{gg}^{-1}\right) \\
& =\text { AA-derived }{ }^{13} \mathrm{C}_{\text {sample }} \times[\mathrm{C}]_{\text {sample }}\left(\mu \mathrm{gg}^{-1}\right)
\end{aligned}
$$

where $[\mathrm{C}]_{\text {sample }}$ is the concentration of total $\mathrm{C}$ in the sample.

Net uptake of AA-derived ${ }^{13} \mathrm{C}$, expressed in percent (\%) of $\mathrm{AA}^{13} \mathrm{C}$ initially supplied to the solution, was calculated using Eq. (4):

$$
\begin{aligned}
& \text { AA-derived }{ }^{13} \mathrm{C} \text { uptake }=(\%) \text { recovery AA-derived } \\
& { }^{13} \mathrm{C}\left(\mathrm{mg} \mathrm{g}^{-1}\right) \times \mathrm{dwt}_{\text {sample }}(\mathrm{g}) / \\
& \mathrm{AA}^{13} \mathrm{C}_{\text {max supplied }}(\mathrm{mg})
\end{aligned}
$$

where $\mathrm{dwt}_{\text {sample }}$ is the dry weight of sample and $\mathrm{AA}^{13} \mathrm{C}_{\max }$ supplied is the maximum $\mathrm{AA}^{13} \mathrm{C}$ supplied to the solution ( $322 \mathrm{mg}$ of $\mathrm{AA}{ }^{13} \mathrm{C}$ ).

The same calculations were applied to ${ }^{15} \mathrm{~N}$.

\section{Results}

\subsection{Total $\mathrm{C}, \mathrm{N}$ and $\mathrm{AA}$ concentrations in the plants}

After 14 days in the growth solution, the aboveground part of the plants of Festuca arundinacea were $30 \mathrm{~cm}$ high but had not reached maturity or flower development (Fig. 1). The $\mathrm{C} / \mathrm{N}$ ratios of the stems and leaves were similar in the labeled and control plants (8.4 and 9.0), whereas the $\mathrm{C} / \mathrm{N}$ ratios of roots were higher in labeled (11.0) than in control 
(4.2) plants (Table 1; Fig. 2). Recovered AAs accounted for $52 \mathrm{mg} \mathrm{C} \mathrm{g}^{-1}$ of the dry matter in both roots and leaves. This is a high AA content, also attested by the low $\mathrm{C} / \mathrm{N}$ ratio, in agreement with the high $\mathrm{N}$ level requirement of young plants sufficiently fertilized to support rapid protein synthesis (Mattson, 1980). However AA-derived ${ }^{13} \mathrm{C}$ and AA-derived ${ }^{15} \mathrm{~N}$ only accounted for ca. $13-14 \%$ of total $\mathrm{C}$ and $40 \%$ of total $\mathrm{N}$. This $\mathrm{N}$ contribution was lower than what might be expected. Indeed, at any stage of growth, AAs (in the form of proteins or free molecules) should account for more than $50 \%$ of grass $\mathrm{N}$. This discrepancy can be attributed to an underestimation of AAs by the extraction-purification process (i.e., incomplete hydrolysis recovery due to recombination into strong acids, and incomplete silylation). An underestimation of the AAs is consistent with the fact that amino-acid TBDMS derivatives, such as tryptophane or cystine (the cystine dimer), could not be recovered. However such an underestimation should not bias the measured relative proportion of methionine, phenylalanine and alanine.

\subsection{Excess, uptake and recovery of AA-derived ${ }^{13} \mathrm{C}$ and $\mathrm{AA}$-derived ${ }^{15} \mathrm{~N}$ in the plants}

The $\delta$ values of the roots and aerial parts of the control plants were respectively -31.0 and $-31.7 \%$ for $\delta^{13} \mathrm{C}$ and 13.8 and $14.5 \%$ for $\delta^{15} \mathrm{~N}$ (Table 1). These values were in the range of the ones measured for $\mathrm{C}_{3}$ grasses in natural conditions ( $\delta^{13} \mathrm{C}$ from -22 to $-34 \%$; e.g., O'Leary, 1988), ensuring that $\mathrm{CO}_{2}$ potentially produced by decomposition of the ${ }^{13} \mathrm{C}-$ labeled molecules inside the tanks did not contaminate the growing chamber atmosphere. The amount of labeled $\mathrm{C}$ recovered in plants and phytoliths was thus considered as exclusively resulting from root uptake.

The low number of replicates (two labeled tanks and two molecular extracts per sample) was a compromise basically constrained by the large amount of matter required to isolate phytolith-occluded $\mathrm{C}$ and the experimental/analysis/cost effort. Table 1 shows that standard deviations calculated on the two replicates were always 1 order of magnitude lower than the mean values.

Relative to plants from the control tank, plants from the labeled tanks were enriched by 0.05 in ${ }^{13} \mathrm{C}$ and $0.5 \%$ in ${ }^{15} \mathrm{~N}$ in the roots and by 0.02 in ${ }^{13} \mathrm{C}$ and $0.3 \%$ in ${ }^{15} \mathrm{~N}$ in the stems and leaves (Table 1).

Overall, the net uptake of AA-derived ${ }^{13} \mathrm{C}$ and AA-derived ${ }^{15} \mathrm{~N}$ by the plant represented respectively 4.5 and $46.9 \%$ of the $\mathrm{AA}^{13} \mathrm{C}$ and $\mathrm{AA}^{15} \mathrm{~N}$ added to the solution (Table 1). Whereas $35 \%$ of absorbed AA-derived ${ }^{13} \mathrm{C}$ and $19.2 \%$ of absorbed AA-derived ${ }^{15} \mathrm{~N}$ were stored in the roots, 64.4 and $81.1 \%$ of the absorbed AA-derived ${ }^{13} \mathrm{C}$ and AA-derived ${ }^{15} \mathrm{~N}$, respectively, were allocated to the stems and leaves (after Table 1). The associated AA-derived $\left({ }^{13} \mathrm{C} /{ }^{15} \mathrm{~N}\right)$ ratios were 0.8 in the roots and 0.3 in the stems and leaves (Table 1, Fig. 2).

Concentrations of AA-derived ${ }^{13} \mathrm{C}$ and AA-derived ${ }^{15} \mathrm{~N}$ represented only 0.13 of total $\mathrm{C}$ and $2.8 \%$ of total $\mathrm{N}$ of the plant (Table 1; Fig. 2). This contribution was higher in roots $(0.28$ of $\mathrm{C}$ and $4.1 \%$ of $\mathrm{N})$ than in stems and leaves $(0.10$ of $\mathrm{C}$ and $2.6 \%$ of $\mathrm{N}$ ). In roots, AA-derived ${ }^{13} \mathrm{C}$ was more concentrated in AAs than in total plant matter $(0.70$ vs. $0.28 \%$ of C) (Table 1). When translocated to leaves, AA-derived ${ }^{13} \mathrm{C}$ concentration in AAs decreased to reach that of the bulk leaf matter $(0.10 \%$ of $\mathrm{C})$ (Table 1$)$.

Among the measured AAs in plant, alanine and phenylalanine were more abundant by more than a factor 10 relative to methionine (Table 1). However, alanine was not more enriched in ${ }^{13} \mathrm{C}$ than most of the AAs (Fig. 3). Instead, phenylalanine and methionine were significantly more enriched in ${ }^{13} \mathrm{C}$ than other AAs in roots, stems and leaves (Fig. 4).

\subsection{Concentrations of phytoliths, phytC, phytN, AA-derived ${ }^{13} \mathrm{C}$ and $\mathrm{AA}$-derived ${ }^{15} \mathrm{~N}$ in phytC and phytN}

Silica content measured by ICP-AES accounted for 0.08 and $0.26 \%$ of the dry weight of roots and stems/leaves, respectively, which is lower than the $>1 \% \mathrm{~d}$ wt concentration previously measured for this species harvested 8 weeks after sowing (Hartley et al., 2015). This is possibly due to the fact that the plants did not reach maturity and/or the volume of the roots in contact with the Si-enriched solution was small, limited by the RHYZOtest configuration. Most of the stems' and leaves' silica was in the form of phytoliths $(0.19 \% \mathrm{~d} w \mathrm{wt})$ (Table 2), which constituted a morphological assemblage characteristic of the Festucoideae grass subfamily to which Festuca arundinacea belongs (Honaine et al., 2006) (Fig. 4). As expected, root phytoliths were not abundant enough to be quantified. PhytC represented $0.51 \% \mathrm{~d}$ wt of phytoliths (Table 2), which is in the range of values previously measured for phytC (Santos et al., 2010; Alexandre et al., 2015; Reyerson et al., 2015). Occluded N (phytN) accounted for $0.10 \%$ $\mathrm{d}$ wt of phytoliths.

Phytoliths were slightly more enriched in ${ }^{13} \mathrm{C}\left({ }^{13} \mathrm{C}\right.$ excess of $0.026 \pm 0.002 \%)$ than the leaves $\left({ }^{13} \mathrm{C}\right.$ excess of $0.017 \pm 0.001 \%)(p$ value $<0.05)$ (Table 1). The AA-derived ${ }^{13} \mathrm{C}$ concentration in phytoliths represented $0.15 \pm 0.01 \%$ of phytC, which is low but on the same order of magnitude as the concentrations in the bulk matter and AAs of stems and leaves $(0.10 \pm 0.003)$ (Table 1). The AA-derived $\left({ }^{13} \mathrm{C} /{ }^{15} \mathrm{~N}\right)$ ratio in phytoliths was low (0.8) but higher than in bulk stems and leaves (0.3) (Table 1; Fig. 2).

\section{Discussion}

\subsection{Plausible forms of AA-derived ${ }^{13} \mathrm{C}$ and AA-derived ${ }^{15} \mathrm{~N}$ absorbed and translocated}

Festuca arundinacea may have absorbed AA-derived ${ }^{13} \mathrm{C}$ and AA-derived ${ }^{15} \mathrm{~N}$ from the labeled solution in multiple organic and inorganic forms, as detailed below. The AAderived $\left({ }^{13} \mathrm{C} /{ }^{15} \mathrm{~N}\right)$ ratios of roots and leaves that were much 


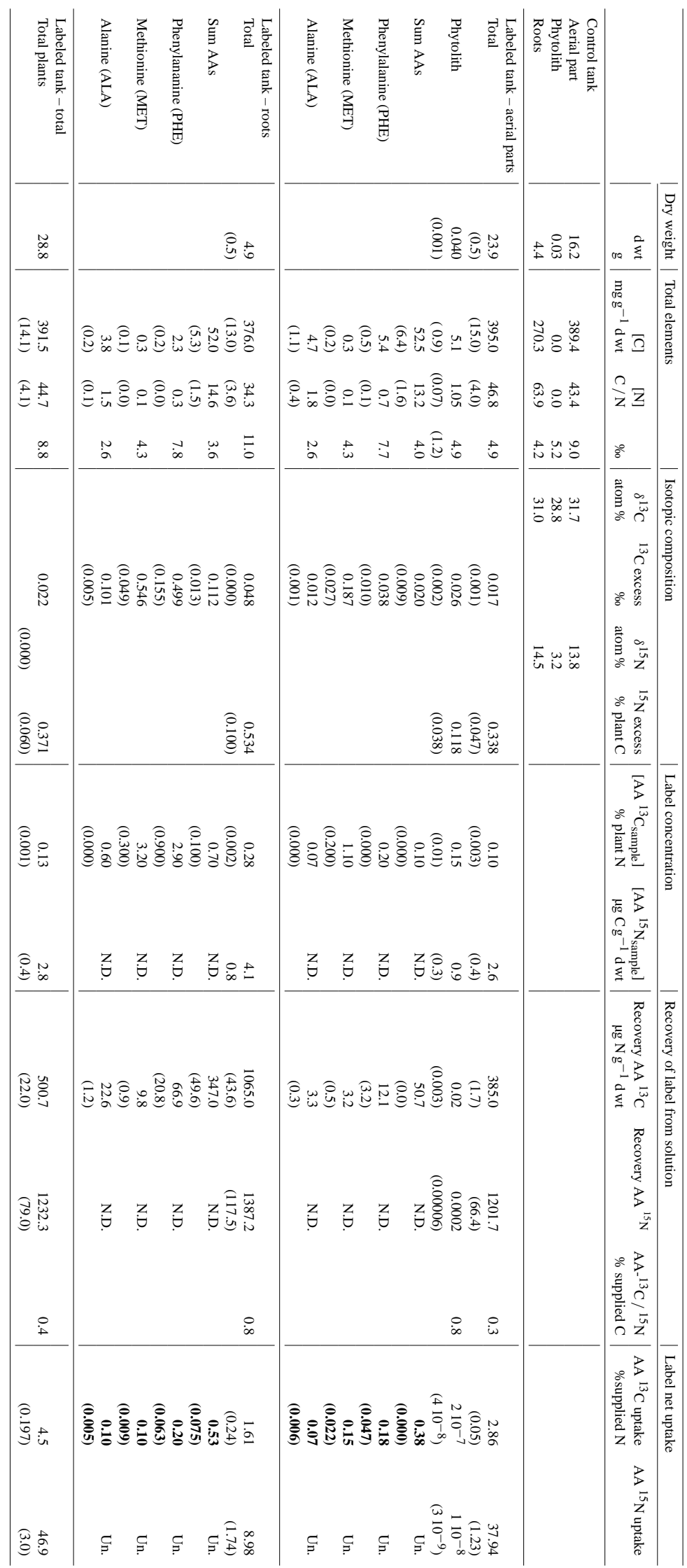




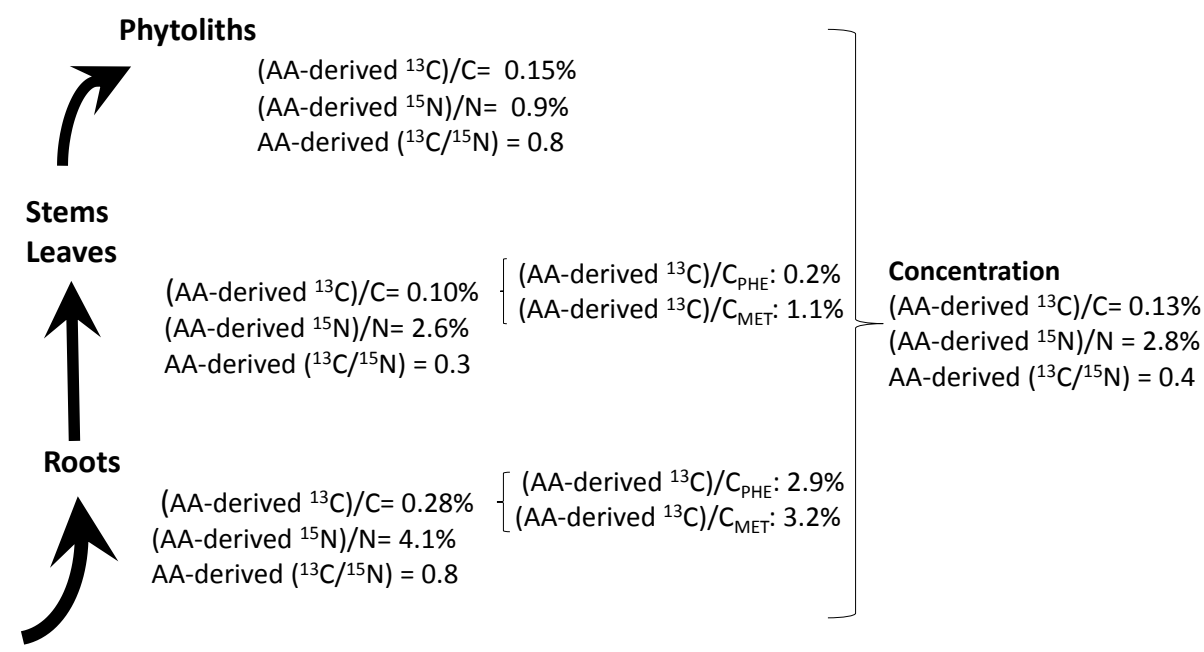

Solution

Figure 2. Concentration of AA-derived ${ }^{13} \mathrm{C}$ and AA-derived ${ }^{15} \mathrm{~N}$ in bulk matter, phenylalanine (PHE) and methionine (MET) of roots, stems and leaves, and phytoliths of Festuca arundinacea grown in labeled tanks (in \% of bulk C, N, PHE and MET).

(a) $\mathrm{C}$ (mg/g dry matter)
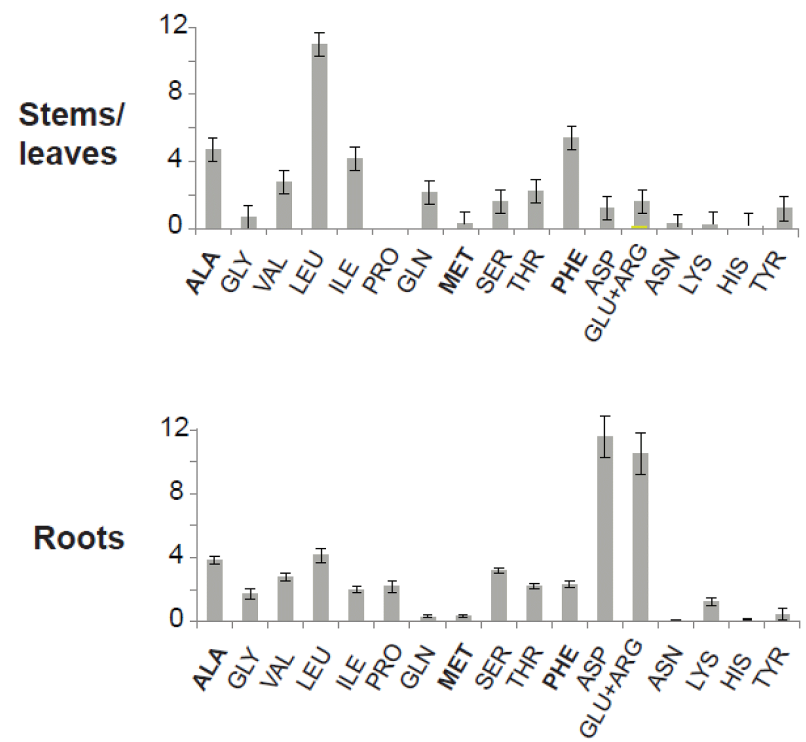

(b) ${ }^{13} \mathrm{C}$-excess (\%)
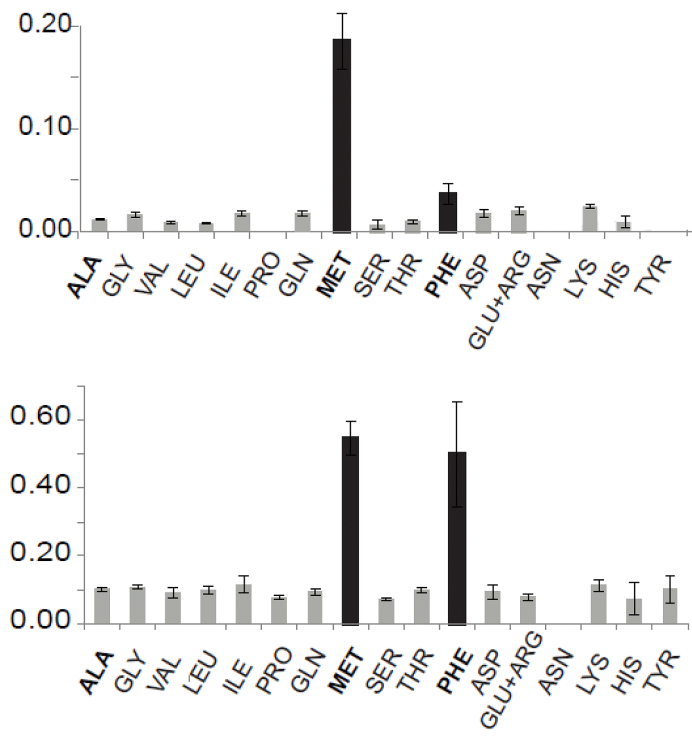

Figure 3. Concentration (a) and ${ }^{13} \mathrm{C}$ excess (b) of amino acids (AAs) measured by GC-IRMS in roots, stems and leaves. Bars stand for 1 standard deviation of four replicates ( 2 tanks $\times 2$ AA extractions).

lower than $\mathrm{C} / \mathrm{N}$ ratios of the supplied AAs (from 2.6 to 7.7) suggested that the grass absorbed most of ${ }^{15} \mathrm{~N}$ from already mineralized $\mathrm{N}$ in the tank. Indeed, under non-sterile conditions, microbial activity around roots can biodegrade the AAs in a range of hours (Jones et al., 2005, 2009; Kielland et al., 2007 ) and produce derived metabolites plus mineralized $\mathrm{N}$ and $\mathrm{CO}_{2}$ (Biernath et al., 2008; Rasmussen et al., 2010). Regarding $\mathrm{C}$, both organic and inorganic forms may enter into the plant (Biernath et al., 2008; Rasmussen et al., 2010). Inor- ganic $\mathrm{C}$ can be transported through the plant passively, linked to transpiration (Vuorinen et al., 1989), and contribute to the $\mathrm{C}$ budget of the leaves through decarboxylation of the dissolved $\mathrm{CO}_{2}$ and photosynthetic refixation of released $\mathrm{CO}_{2}$ (anaplerotic fixation; Viktor and Cramer, 2005). Both organic and inorganic compounds can thus be used in the build-up of new molecules or as energetic resources (e.g., Näsholm et al., 2009), or be lost through respiration (Gioseffi et al., 2012) or exudates (e.g., Jones and Darrah, 1993). Organic C can also 


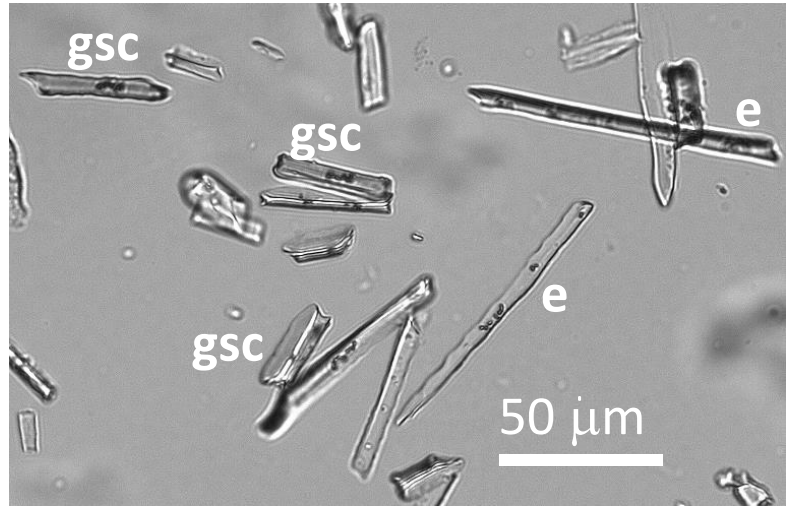

Figure 4. Natural light microscopy image of the phytolith assemblage produced by the stems and leaves of Festuca arundinacea dominated by (e) the elongate type and (gsc) the grass short cell trapeziform type (Madella et al., 2005).

Table 2. Concentration of phytoliths, phytolith occluded C (PhytC) and phytolith occluded $\mathrm{N}$ (PhytN) in Festuca arundinacea grown in labeled and control solutions. Numbers in italics refer to the standard deviation associated with the averaged values (one value per labeled tank).

\begin{tabular}{lrrr}
\hline & Phytolith & PhytC & PhytN \\
\cline { 2 - 4 } & \% dwt plant & \% dwt phytolith \\
\hline Control tank & & & \\
Aerial part & 0.102 & 0.88 & 0.17 \\
Roots & 0.075 & & \\
\hline Labeled tank & & & \\
Aerial parts & 0.19 & 0.51 & 0.1 \\
& $(0.002)$ & $(0.08)$ & $(0.007)$ \\
Roots & 0.014 & & \\
& $(0.01)$ & & \\
\hline
\end{tabular}

enter the plant as intact molecules, such as AAs (Sauheitl et al., 2009; Whiteside et al., 2009), and be either translocated by AA transporters or subject to deamination. Lastly, rhizospheric and endophytic microorganisms that acquired their labeled signature from the labeled solution may also account for the AA-derived ${ }^{13} \mathrm{C}$ and AA-derived ${ }^{15} \mathrm{~N}$ recovery in the plant.

The present labeling experiment does not allow for precise tracing of the form in which the AA-derived ${ }^{13} \mathrm{C}$ and AA-derived ${ }^{15} \mathrm{~N}$ were absorbed and fixed in roots, stems and leaves, as recently done using a position-specific $\mathrm{C}$ - and $\mathrm{N}$ labeling technique (Moran-Zuloaga et al., 2015). All the processes described above may have occurred jointly. The significant decrease of ${ }^{13} \mathrm{C}$ excess (or AA-derived ${ }^{13} \mathrm{C}$ concentration) in AAs from roots to leaves ( $p$ value $<0.05$ ) (Figs. 2 and 3) suggested either an uptake and fixation of organic ${ }^{13} \mathrm{C}$ or an anaplerotic fixation of inorganic ${ }^{13} \mathrm{C}$ in the roots themselves. However, the fact that ${ }^{13} \mathrm{C}$ was more concentrated in the extracted AAs than in bulk roots and stems/leaves (Table 1; Fig. 2) and, further, that ${ }^{13} \mathrm{C}$ excess values of methionine and phenylalanine were significantly higher than ${ }^{13} \mathrm{C}$ excess values of other AAs in the roots and stems/leaves (Fig. 3) evidenced that a small amount of $\mathrm{AA}^{13} \mathrm{C}$ entered the plant and was subsequently translocated and fixed in roots and stems/leaves in its original molecular form.

\section{2 $\mathrm{AA}^{13} \mathrm{C}$ fixation in phytoliths}

In agreement with the radiocarbon evidence for soil $\mathrm{C}$ occlusion in phytoliths (Reyerson et al., 2015), AA-derived ${ }^{13} \mathrm{C}$ accounted for a measurable part of phytC. The phytolith $\mathrm{C} / \mathrm{N}$ value (5.0) was close to a value previously measured in cultivated wheat phytoliths (3.7; Alexandre et al., 2015) and in the range of $\mathrm{C} / \mathrm{N}$ values characteristic of AAs (45; Jones et al., 2009). However, the AA-derived ${ }^{13} \mathrm{C} /{ }^{15} \mathrm{~N}$ ratio $(0.8)$ was far from this range. Thus, although our experiment tracked for the first time the $\mathrm{C}$ from its absorption by grass roots to its fixation in organic compounds subject to occlusion in stem and leaf phytoliths, the forms in which AA-derived ${ }^{13} \mathrm{C}$ entered the plant, was translocated and ultimately occluded in phytoliths still remain unknown.

Previous nano-scale secondary ion mass spectrometry (NanoSIMS) investigation of phytC indicated that at least part of phytC is continuously distributed in the silica structure, at the sub-micrometric scale (Alexandre et al., 2015). This has been further supported by Raman spectroscopy mapping (Gallagher et al., 2015). The process of silica precipitation has been investigated by environmental scanning electron microscope (ESEM) and transmission electron microscopy-energy-dispersive X-ray spectrometry (TEMEDX) analyses, which have highlighted that silica first precipitates in the inner cell wall, probably triggered by the presence of callose or lignin, and then infills the cell lumen in a centripetal way until most of the cell becomes silicified (e.g., Perry et al., 1987; Motomura, 2004; Laue et al., 2007; Law and Exley, 2011; Zhang et al., 2013). During this process, an organic template probably participates in the silica formation (Harrison. 1996; Laue et al., 2007). When the cell silicification is complete, residual organic compounds that were not already occluded probably gather in any remaining spaces within the cell and delimitate micrometric central cavities characteristic of most phytoliths (Alexandre et al., 2015). In the present case, the concentration of AA-derived ${ }^{13} \mathrm{C}$ (relative to total $\mathrm{C}$ ) in phytoliths, which is on the same order of magnitude as in leaves, supports a random fixation of AA-derived ${ }^{13} \mathrm{C}$ in these residual organic compounds subject to occlusion in the silica structure. There are two plausible hypotheses for this fixation. The first hypothesis is that AA-derived ${ }^{13} \mathrm{C}$ may be associated with $\mathrm{Si}$ when absorbed by the roots, translocated in the plant and introduced into the cells. However, ${ }^{29} \mathrm{Si}$ NMR spectroscopy of ${ }^{29} \mathrm{Si}$-labeled exudate of wheat xylem previously indicates only the occurrence of the dissolved forms of Si (Casey et al., 2004). Although 
this does not preclude the subsequent formation of organosilicate complexes, it weakens the hypothesis of $\mathrm{Si}$ and $\mathrm{C}$ being associated since their uptake by the roots. Additionally, in our experiment, the roots that contain the lowest amount of $\mathrm{Si}$ also contain the highest amount of AA-derived ${ }^{13} \mathrm{C}$, which is not in agreement with AA-derived ${ }^{13} \mathrm{C}$ and $\mathrm{Si}$ being associated when absorbed by the roots. The second hypothesis is that AA-derived ${ }^{13} \mathrm{C}$ may be isolated as an unwanted substance in cell vacuoles and subsequently trapped in the silica structure. In order to check this hypothesis, we used D-ALA, expected to be less metabolized than L-AAs, although recent investigations suggest that plants are able to utilize D-AAs at rate comparable to those of other $\mathrm{N}$ forms (Hill et al., 2011). D-ALA was not specifically taken up or retained as an intact molecule (Fig. 3) and cannot account for the AA-derived ${ }^{13} \mathrm{C}$ measured in phytC. D-ALA may thus not be appropriate for tracing unwanted substances. Further investigations, including the use of spectroscopies relevant for characterizing phytC at the molecular level, are necessary to support or refute the above hypotheses.

\subsection{Implication for our understanding of the $C$ cycle at the plant-soil interface}

In the experiments presented here, the net uptake of AAderived ${ }^{13} \mathrm{C}$ by Festuca arundinacea represented $4.5 \%$ of AA-derived ${ }^{13} \mathrm{C}$ supplied to the nutrient solution, part of it being absorbed as intact AA molecules (here methionine and phenylalanine). AA-derived ${ }^{13} \mathrm{C}$ fixed in the plant represented only $0.13 \%$ of total C, the root absorption of AAderived ${ }^{13} \mathrm{C}$ being clearly marginal compared to photosynthesis. The present experiment was done in nutrient solution, and its relevance for soil $\mathrm{C}$ uptake assessment is therefore limited. It may underestimate the extent of the process under natural and field conditions. Indeed, AA uptake was shown to be inhibited by the high concentrations of mineral $\mathrm{N}$ preferred by the plant (Paungfoo-Lonhienne et al., 2008; Sauheitl et al., 2009; Gioseffi et al., 2012). In the present case, mineral $\mathrm{N}$ may come from $\mathrm{KNO}_{3}$ initially present in the original nutrient solution and from the supplied AAs dissociated by microbes, mycorrhizas or root exudates (PaungfooLonhienne et al., 2008; Keiluweit et al., 2015). The maximum AA content in the growth solution $\left(0.2 \mathrm{mmol} \mathrm{L}^{-1}\right)$ was higher than AA concentrations that have been measured in soil solutions (from 0 to $0.1 \mathrm{mmol} \mathrm{L}^{-1}$; Vinolas et al., 2001; Jämtgård et al., 2010), thus potentially inhibiting AA uptake. Additionally, due the RHIZOtest configuration, roots were confined to a small volume, and their contact with the renewed labeled solutions and AA-derived ${ }^{13} \mathrm{C}$ available for uptake was limited. Given the above considerations, the use of the AA-derived ${ }^{13} \mathrm{C}$ concentrations, experimentally measured, as a proxy of soil-derived $\mathrm{C}$ concentrations should be considered with caution.

However, to gain a rough idea on the order of magnitude of the C flux that may occur from soil to plant, at the ecosys- tem scale we used the $0.13 \%$ AA-derived ${ }^{13} \mathrm{C}$ concentration in plants obtained in the present experiment and extrapolated that value to the grassland ecosystem scale. Grasslands cover a global surface of $2.4 \times 10^{9}$ ha (Scurlock and Hall, 1998) and are characterized by a net primary production (NPP) ranging from 7 to $20 \times 10^{9} \mathrm{t} \mathrm{C} \mathrm{ha}^{-1} \mathrm{yr}^{-1}$ (Scurlock et al., 2002). The global grassland productivity thus ranges from 16.8 to $48 \times 10^{9} \mathrm{t} \mathrm{C} \mathrm{yr}^{-1}$. The obtained flux of AA-derived $\mathrm{C}$ absorbed by grasses then would range from 21.8 to $62.4 \times 10^{6} \mathrm{t} \mathrm{C} \mathrm{yr}^{-1}$. This is nonsignificant when compared to the $2.6 \times 10^{9} \mathrm{t} \mathrm{C} \mathrm{yr}^{-1}$ estimate for the land $\mathrm{C}$ sink (IPCC Staff, 2007), or to the $0.4 \times 10^{9} \mathrm{t} \mathrm{C} \mathrm{yr}^{-1}$ estimate for the global long-term soil $\mathrm{C}$ accumulation rate (Schlesinger, 1990). It is, however, higher than a possible $\mathrm{CO}_{2}$ phytolith biosequestration flux (e.g., Parr and Sullivan, 2005; Parr et al., 2010; Song et al., 2014). The $\mathrm{CO}_{2}$ phytolith biosequestration concept is based on the assumptions that phytC is exclusively derived from atmospheric $\mathrm{CO}_{2}$ and has a long residence time in soils. A recent re-examination of the $\mathrm{CO}_{2}$ biosequestration flux by phytoliths, in the light of a lower and more realistic estimates of phytolith residence time in soils, yielded a value of $4.1 \times 10^{4} \mathrm{t} \mathrm{C} \mathrm{yr}^{-1}$ for grasslands worldwide (Reyerson et al., 2015). The present study further minimizes the significance of $\mathrm{CO}_{2}$ biosequestration by phytoliths, showing that it could be counteracted by the flux of $\mathrm{C}$ potentially mobilized from soils by grass root uptake.

Recent experiments have demonstrated that root exudates promote a net loss of soil C previously assumed to be stable at the millennial scale thanks to its protection by mineral constituents (e.g., clays or amorphous minerals). Root exudates would stimulate microbial and fungi digestion (priming effect) (Fontaine et al., 2003, 2011) and promote dissolution of the mineral phase through an oxalic acid production experiment; we suggest that direct uptake of soil-derived $\mathrm{C}$ by roots, in conjunction with the $\mathrm{N}$ uptake, should be accounted for when investigating the role of roots in soil $\mathrm{C}$ mobilization.

\section{Conclusions}

In agreement with previous studies, the present labeling experiment supports the finding that $\mathrm{C}$ absorbed by grass roots and allocated to stems and leaves preserves to a small extent its original organic molecular form (here methionine and phenylalanine). Moreover, the experiment shows for the first time that AA-derived $\mathrm{C}$ absorbed by grass roots and allocated to stems and leaves can partly feed the $\mathrm{C}$ ultimately fixed in organic compounds subject to occlusion in stem and leaf silica. Further analyses are required to identify the form in which AA-derived $\mathrm{C}$ and more generally phytC is occluded. Our findings complement previous radiocarbon evidence of soil C contribution to phytC (Santos et al., 2012; Reyerson et al., 2015) and raise questions about the mechanisms that drive soil $\mathrm{C}$ mobilization by plant roots, which need to be an- 
swered for a better understanding of soil-plant interactions involved in the terrestrial $\mathrm{C}$ cycle.

Acknowledgements. This study was supported by the OSU-Institut Pythéas (Aix-Marseille Université-CNRS-IRD), the French Labex OT-Med (grant 2013 to A. Alexandre for the project "Revealing the source of carbon occluded in phytoliths (phytC): potential implication concerning the role of plant Si cycling on carbon cycling") and by the US National Science Foundation (DEB-1144888 to G. M. Santos). A. Harutyunyan and G. M. Santos would like to thank X. Xu for technical support during the stable isotope analysis at UCI and Q. Lin for assistance with X-ray analytical techniques at the Laboratory for Electron and X-ray Instrumentation (LEXI), also at UCI.

Edited by: Y. Kuzyakov

\section{References}

Alexandre, A., Bouvet, M., and Abbadie, L.: The role of savannas in the terrestrial Si cycle: A case-study from Lamto, Ivory Coast, Glob. Planet. Change, 78, 162-169, 2011.

Alexandre, A., Basile-Doelsch, I., Delhaye, T., Borshneck, D., Mazur, J. C., Reyerson, P., and Santos, G. M.: New highlights of phytolith structure and occluded carbon location: 3-D X-ray microscopy and NanoSIMS results, Biogeosciences, 12, 863-873, doi:10.5194/bg-12-863-2015, 2015.

Amelung, W., Zhang, X., and Flach, K. W.: Amino acids in grassland soils: climatic effects on concentration and chirality, Geoderma, 130, 207-217, 2006.

Bardgett, R. D., Streeter, T. C., and Bol, R.: Soil Microbes Compete Effectively with Plants for Organic-Nitrogen Inputs to Temperate Grasslands, Ecology, 84, 1277-1287, 2003.

Biernath, C., Fischer, H., and Kuzyakov, Y.: Root uptake of Ncontaining and $\mathrm{N}$-free low molecular weight organic substances by maize: A $14 \mathrm{C} / 15 \mathrm{~N}$ tracer study, Soil Biol. Biochem., 40, 2237-2245, 2008.

Bol, R., Poirier, N., Balesdent, J., and Gleixner, G.: Molecular turnover time of soil organic matter in particle-size fractions of an arable soil, Rapid Commun. Mass Spectrom. RCM, 23, 25512558, 2009.

Bravin, M. N., Michaud, A. M., Larabi, B., and Hinsinger, P.: RHIZOtest: a plant-based biotest to account for rhizosphere processes when assessing copper bioavailability, Environ. Pollut., 158, 3330-3337, 2010.

Casey, W. H., Kinrade, S. D., Knight, C. T. G., Rains, D. W., and Epstein, E.: Aqueous silicate complexes in wheat, Triticum aestivum L., Plant Cell Environ., 27, 51-54, 2004.

Conley, D. J.: Terrestrial ecosystems and the global biogeochemical silica cycle, Glob. Biogeochem. Cy., 16, 1-8, 2002.

Corbineau, R., Reyerson, P. E., Alexandre, A., and Santos, G. M.: Towards producing pure phytolith concentrates from plants that are suitable for carbon isotopic analysis, Rev. Palaeobot. Palynol., 197, 179-185, 2013.

Crespin, J., Alexandre, A., Sylvestre, F., Sonzogni, C., Pailles, C., and Garreta, V.: IR laser extraction technique applied to oxygen isotope analysis of small biogenic silica samples, Anal. Chem., 80, 2372-2378, 2008.
Fontaine, S., Mariotti, A., and Abbadie, L.: The priming effect of organic matter: a question of microbial competition?, Soil Biol. Biochem., 35, 837-843, 2003.

Fontaine, S., Henault, C., Aamor, A., Bdioui, N., Bloor, J. M. G., Maire, V., Mary, B., Revaillot, S., and Maron, P. A.: Fungi mediate long term sequestration of carbon and nitrogen in soil through their priming effect, Soil Biol. Biochem., 43, 86-96, 2011.

Gallagher, K. L., Alfonso-Garcia, A., Sanchez, J., Potma, E. O., and Santos, G. M.: Plant growth conditions alter phytolith carbon, Plant Physiol., 753, doi:10.3389/fpls.2015.00753, 2015.

Gibson, D. J. and Newman, J. A.: Festuca arundinacea Schreber (F. elatior L. ssp. arundinacea (Schreber) Hackel), J. Ecol., 89, 304-324, 2001.

Gioseffi, E., de Neergaard, A., and Schjoerring, J. K.: Interactions between uptake of amino acids and inorganic nitrogen in wheat plants, Biogeosciences, 9, 1509-1518, doi:10.5194/bg-9-15092012, 2012.

Guigues, S., Bravin, M. N., Garnier, C., Masion, A., and Doelsch, E.: Isolated cell walls exhibit cation binding properties distinct from those of plant roots, Plant Soil, 381, 367-379, 2014.

Hartley, S. E., Fitt, R. N., McLarnon, E. L., and Wade, R. N.: Defending the leaf surface: intra- and inter-specific differences in silicon deposition in grasses in response to damage and silicon supply, Front. Plant Sci., 6, 35, doi:10.3389/fpls.2015.00035, 2015.

Heimann, M. and Reichstein, M.: Terrestrial ecosystem carbon dynamics and climate feedbacks, Nature, 451, 289-292, 2008.

Hill, P. W., Quilliam, R. S., DeLuca, T. H., Farrar, J., Farrell, M., Roberts, P., Newsham, K. K., Hopkins, D. W., Bardgett, R. D., and Jones, D. L.: Acquisition and Assimilation of Nitrogen as Peptide-Bound and D-Enantiomers of Amino Acids by Wheat, PLoS ONE, 6, e19220, doi:10.1029/2008GB003250, 2011.

Honaine, M. F., Osterrieth, M. L., and Zucol, A. F.: Plant communities and soil phytolith assemblages relationship in native grasslands from southeastern Buenos Aires province, Argentina, Catena, 76, 89-96, 2009.

IPCC Staff: Climate Change: Synthesis Report. Contribution of Working Groups I, II and III to the Fourth Assessment Report of the Intergovernmental Panel on Climate Change, 2007.

Jämtgård, S., Näsholm, T., and Huss-Danell, K.: Nitrogen compounds in soil solutions of agricultural land, Soil Biol. Biochem., 42, 2325-2330, 2010.

Jones, D. L. and Darrah, P. R.: Re-sorption of organic components by roots of Zea mays L. and its consequences in the rhizosphere, Plant Soil, 143, 259-266, 1992.

Jones, D. L. and Darrah, P. R.: Re-sorption of organic compounds by roots of Zea mays L. and its consequences in the rhizosphere, Plant Soil, 153, 47-59, 1993.

Jones, D. L. and Darrah, P. R.: Re-sorption of organic compounds by roots of Zea mays L. and its consequences in the rhizosphere, Plant Soil, 178, 153-160, 1996.

Jones, D. L., Shannon, D., Junvee-Fortune, T., and Farrar, J. F.: Plant capture of free amino acids is maximized under high soil amino acid concentrations, Soil Biol. Biochem., 37, 179-181, 2005.

Jones, D. L., Nguyen, C., and Finlay, R. D.: Carbon flow in the rhizosphere: carbon trading at the soil-root interface, Plant Soil, 321, 5-33, 2009a.

Jones, D. L., Kielland, K., Sinclair, F. L., Dahlgren, R. A., Newsham, K. K., Farrar, J. F., and Murphy, D. V.: Soil organic nitro- 
gen mineralization across a global latitudinal gradient, Global Biogeochem. Cy., 23, GB1016, doi:10.1038/nclimate2580, 2009b.

Keiluweit, M., Bougoure, J. J., Nico, P. S., Pett-Ridge, J., Weber, P. K., and Kleber, M.: Mineral protection of soil carbon counteracted by root exudates, Nat. Clim. Change, doi:10.1186/14712229-11-112, 2015.

Kielland, K., McFarland, J. W., Ruess, R. W., and Olson, K.: Rapid Cycling of Organic Nitrogen in Taiga Forest, Ecosystems, 10, 360-368, 2007.

Kuzyakov, Y. and Jones, D. L.: Glucose uptake by maize roots and its transformation in the rhizosphere, Soil Biol. Biochem., 38, 851-860, 2006.

Laue, M., Hause, G., Dietrich, D., and Wielage, B.: Ultrastructure and microanalysis of silica bodies in Dactylis Glomerata L., Microchim. Acta, 156, 103-107, 2007.

Law, C. and Exley, C.: New insight into silica deposition in horsetail (Equisetum arvense), BMC Plant Biol., 11, 112, doi:10.1186/1471-2229-11-112, 2011.

Madella, M., Alexandre, A., Ball, T., and Grp, I. W.: International Code for Phytolith Nomenclature 1.0, Ann. Bot., 96, 253-260, 2005.

Mattson, W. J.: Herbivory in Relation to Plant Nitrogen Content, Annu. Rev. Ecol. Syst., 11, 119-161, 1980.

Moran-Zuloaga, D., Dippold, M., Glaser, B., and Kuzyakov, Y.: Organic nitrogen uptake by plants: reevaluation by position-specific labeling of amino acids, Biogeochemistry, 125, 359-374, 2015.

Motomura, H.: Silica Deposition in Relation to Ageing of Leaf Tissues in Sasa veitchii (CarrieÁre) Rehder (Poaceae: Bambusoideae), Ann. Bot., 93, 235-248, 2004.

Näsholm, T., Kielland, K., and Ganeteg, U.: Uptake of organic nitrogen by plants, New Phytol., 182, 31-48, 2009.

O'Leary, M. H.: Carbon Isotopes in Photosynthesis, BioScience, 38, 328-336, 1988.

Parr, J. F. and Sullivan, L. A.: Soil carbon sequestration in phytoliths, Soil Biol. Biochem., 37, 117-124, 2005.

Parr, J., Sullivan, L., Chen, B., Ye, G., and Zheng, W.: Carbon biosequestration within the phytoliths of economic bamboo species, Glob. Change Biol., 16, 2661-2667, 2010.

Paungfoo-Lonhienne, C., Lonhienne, T. G. A., Rentsch, D., Robinson, N., Christie, M., Webb, R. I., Gamage, H. K., Carroll, B. J., Schenk, P. M., and Schmidt, S.: Plants can use protein as a nitrogen source without assistance from other organisms, Proc. Natl. Acad. Sci., 105, 4524-4529, 2008.

Perry, C. C., Williams, R. J. P., and Fry, S. C.: Cell Wall Biosynthesis during Silicification of Grass Hairs, J. Plant Physiol., 126, 437-448, 1987.

Rasmussen, J., Sauheitl, L., Eriksen, J., and Kuzyakov, Y.: Plant uptake of dual-labeled organic $\mathrm{N}$ biased by inorganic $\mathrm{C}$ uptake: Results of a triple labeling study, Soil Biol. Biochem., 42, 524$527,2010$.
Reyerson, P. E., Alexandre, A., Harutyunyan, A., Corbineau, R., Martinez De La Torre, H. A., Badeck, F., Cattivelli, L., and Santos, G. M.: Evidence of old soil carbon in grass biosilica particles, Biogeosciences Discuss., 12, 15369-15410, doi:10.5194/bgd12-15369-2015, 2015.

Rubino, M., Milin, S., D’Onofrio, A., Signoret, P., Hatté, C., and Balesdent, J.: Measurement of $\delta 13 \mathrm{C}$ values of soil amino acids by GC-C-IRMS using trimethylsilylation: a critical assessment, Isotopes Environ, Health Stud., 50, 516-530, 2014.

Santos, G. M., Alexandre, A., Coe, H. G., Reyerson, P. E., Southon, J. R., and De Carvalho, C. N.: The Phytolith ${ }^{14}$ C Puzzle: A Tale of Background Determinations and Accuracy Tests, Radiocarbon, 52, 113-128, 2010.

Santos, G. M., Alexandre, A., Southon, J. R., Treseder, K. K., Corbineau, R., and Reyerson, P. E.: Possible source of ancient carbon in phytolith concentrates from harvested grasses, Biogeosciences, 9, 1873-1884, doi:10.5194/bg-9-1873-2012, 2012.

Sauheitl, L., Glaser, B., and Weigelt, A.: Uptake of intact amino acids by plants depends on soil amino acid concentrations, Environ. Exp. Bot., 66, 145-152, 2009.

Schlesinger, W. H.: Evidence from chronosequence studies for a low carbon-storage potential of soils, Nature, 348, 232-234, 1990.

Scurlock, J. M. O. and Hall, D. O.: The global carbon sink: a grassland perspective, Glob. Change Biol., 4, 229-233, 1998.

Scurlock, J. M. O., Johnson, K., and Olson, R. J.: Estimating net primary productivity from grassland biomass dynamics measurements, Glob. Change Biol., 8, 736-753, 2002.

Shinebarger, S. R., Haisch, M., and Matthews, D. E.: Retention of carbon and alteration of expected ${ }^{13} \mathrm{C}$-tracer enrichments by silylated derivatives using continuous-flow combustion-isotope ratio mass spectrometry, Anal Chem., 74, 6244-6251, 2002.

Song, Z., Wang, H., Strong, P. J., and Guo, F.: Phytolith carbon sequestration in China's croplands, Eur. J. Agron., 53, 10-15, 2014.

Viktor, A. and Cramer, M. D.: The influence of root assimilated inorganic carbon on nitrogen acquisition/assimilation and carbon partitioning, New Phytol., 165, 157-169, 2005.

Vinolas, L. C., Healey, J. R., and Jones, D. L.: Kinetics of soil microbial uptake of free amino acids, Biol. Fertil. Soils, 33, 67-74, 2001.

Vuorinen, A. H., Vapaavuori, E. M., and Lapinjoki, S.: Time-course of uptake of dissolved inorganic carbon through willow roots in light and in darkness, Physiol. Plant., 77, 33-38, 1989.

Whiteside, M. D., Treseder, K. K., and Atsatt, P. R.: The brighter side of soils: Quantum dots track organic nitrogen through fungi and plants, Ecology, 90, 100-108, 2009.

Zhang, C., Wang, L., Zhang, W., and Zhang, F.: Do lignification and silicification of the cell wall precede silicon deposition in the silica cell of the rice (Oryza sativa L.) leaf epidermis?, Plant Soil, 372, 137-149, 2013. 